\title{
Doses e fontes de nitrogênio na recuperação de pastagens do capim-marandu
}

\author{
[Nitrogen doses and sources on pasture recuperation of grass marandu] \\ K.A.P. Costa ${ }^{1}$, V. Faquin ${ }^{2,4}$, I.P. Oliveira ${ }^{3}$ \\ ${ }^{1}$ Universidade de Rio Verde \\ Caixa Postal 104 \\ 75901-970 - RioVerde, GO \\ ${ }^{2}$ Departamento de Ciência do Solo - UFLA, - Lavras, MG \\ ${ }^{3}$ Faculdade Montes Belos - São Luis de Montes Belos, GO \\ ${ }^{4}$ Bolsista do CNPq
}

\begin{abstract}
RESUMO
Avaliaram-se o efeito de doses e fontes de nitrogênio na recuperação do capim-marandu, por um período de três anos, em pastagem estabelecida há mais de 10 anos, com baixa produção de forragem. O delineamento experimental foi em blocos completos ao acaso, com três repetições. Nas parcelas foi utilizado o fatorial $2 \times 4$, sendo duas fontes de nitrogênio (sulfato de amônio e uréia) e quatro doses de nitrogênio $\left(0,100,200\right.$ e 300kg ha ${ }^{-1}$ ano $\left.^{-1}\right)$. Nas subparcelas, foram alocados os três anos $(2004,2005$ e 2006), referentes ao tempo de recuperação da pastagem. A aplicação de nitrogênio foi determinante para a recuperação do capim-marandu. A maior produção de massa seca foi observada no segundo ano e o maior teor de proteína bruta no terceiro ano de recuperação da pastagem. As maiores doses de nitrogênio promoveram acréscimos lineares na produção de massa seca e redução nos teores de fibra em detergente neutro e fibra em detergente ácido. O sulfato de amônio promoveu maior produção de massa seca do que a ureia, em todas as doses e anos avaliados.
\end{abstract}

Palavras-chave: Brachiaria brizantha, composição bromatológica, massa seca, sulfato de amônio, ureia

\begin{abstract}
The effects of nitrogen doses and sources were evaluated on pasture recuperation of grass marandu, in a three-year period. The pasture was established for more than ten years and it was presenting low herbage production being considered in moderate degradation phase. The experiment was arranged in a randomized complete block design with split-plots and three replications, in a $2 x 4$ factorial, being two sources of $N$ (ammonium sulphate and urea) and four doses of $N\left(0,100,200\right.$, and 300kg ha-1 $\left.\mathrm{yr}^{-1}\right)$. The time of pasture evaluation was represented by the years 2004, 2005, and 2006. The highest dry matter production was observed in the second year and the highest crude protein in the third one. The highest nitrogen doses promoted linear increase on dry mass production and decrease in fiber concentration and in neutral and acid detergents. Ammonium sulphate resulted in higher dry mass production than urea in all doses applied and evaluated years.
\end{abstract}

Keywords: Brachiaria brizantha, dry mass, bromatologic composition, ammonium sulphate, urea

\section{INTRODUÇÃO}

As gramíneas do gênero Brachiaria ocupam posição de destaque na pecuária brasileira. Estima-se que, no Brasil, existam cerca de 200 milhões de hectares de pastagens, sendo $20 \%$ dessa área constituída de pastagens degradadas, apenas com plantas forrageiras desse gênero (Bonfim-da-Silva e Monteiro, 2006). A forma extrativista de exploração pecuária vem aumentando as áreas degradadas de pastagem ou

Recebido em 9 de maio de 2009 
em processo de degradação. Na degradação das pastagens, a produtividade e a composição botânica podem ser substancialmente alteradas ao longo do tempo, devido ao declínio da fertilidade do solo e ao manejo inadequado das plantas forrageiras. $\mathrm{O}$ esgotamento da fertilidade do solo, em consequência da ausência de adubação, tem sido apontado como uma das principais causas da degradação de pastagens cultivadas. A recuperação das pastagens é um dos caminhos para reversão dessa situação, e uma das formas de alcançar esse objetivo é trabalhar com a reconstituição da fertilidade do solo, esgotada pelos anos sucessivos de exploração extrativista, sem a devida atenção ao manejo da pastagem e correção/manutenção da fertilidade do solo, levando essas pastagens à degradação (Costa et al., 2009). Assim, o fornecimento de nutrientes, em quantidades e proporções adequadas, particularmente $\mathrm{o}$ nitrogênio, assume importância fundamental no processo produtivo de pastagens. Isso porque o nitrogênio do solo, proveniente da mineralização da matéria orgânica, não é suficiente para atender à demanda de gramíneas com potencial produtivo (Fagundes et al., 2006).

Dois aspectos são fundamentais no manejo da adubação nitrogenada: a fonte e o parcelamento das doses para diminuir principalmente as perdas por volatilização e lixiviação. Com isso, tem-se melhor aproveitamento do nitrogênio pela planta, redução das perdas e manutenção de taxas de acúmulo mais uniforme de massa seca pela planta (Werner et al., 2001).

Bonfim-da-Silva e Monteiro (2006), em estudo de doses de nitrogênio e enxofre em pastagem degradada de capim-braquiária, verificaram que as doses de nitrogênio foram determinantes para a produção de massa seca das lâminas foliares e dos colmos mais bainhas. Resultados positivos de adubação nitrogenada no capim-braquiária também foram obtidos por Santos Júnior e Monteiro (2003); Alexandrino et al. (2005), Oliveita et al. (2005), Batista e Monteiro (2006). Considerando a importância da adubação nitrogenada em pastagem, essa pesquisa teve o objetivo de avaliar o efeito de doses e fontes de nitrogênio na recuperação do capim-marandu, por um período de três anos.

\section{MATERIAL E MÉTODOS}

O experimento foi realizado de julho de 2003 a março de 2006, na Fazenda Modelo da Universidade Estadual de Goiás (UEG), em São Luís de Montes Belos, GO, a 579m de altitude, $16^{\circ} 31^{\prime} 30^{\prime \prime}$ de latitude Sul e 50'22' $20^{\prime \prime}$ de longitude Oeste. Predomina na região o clima tropical de savana do tipo Aw, conforme classificação de Koppen, com chuvas concentradas no verão (outubro-abril) e estação seca no inverno (maio-setembro).

A área utilizada de pastagem foi de $882 \mathrm{~m}^{2}$, dividida em três blocos de $294 \mathrm{~m}^{2}$, com parcelas individuais de $20 \mathrm{~m}^{2}$ e área útil de $6 \mathrm{~m}^{2}$. A pastagem já se encontrava estabelecida há mais de 10 anos, com baixa produção de forragem, em estágio moderado de degradação, devido à exploração intensiva com animais e falta de reposição de nutrientes no solo.

O delineamento experimental utilizado foi o de blocos completos ao acaso, com três repetições. Nas parcelas, foi utilizado o esquema fatorial $2 \mathrm{x}$ 4, sendo duas fontes de nitrogênio, (sulfato de amônio e uréia), e quatro doses de nitrogênio $(0$, 100,200 e $\left.300 \mathrm{~kg} \mathrm{ha}^{-1} \mathrm{ano}^{-1}\right)$. Nas subparcelas, foram alocados os três anos, (2004, 2005 e 2006) referentes ao tempo de avaliação da pastagem.

O solo foi classificado como Latossolo Vermelho, de textura argilosa, cujas médias das características químicas do solo, na profundidade de $0-20 \mathrm{~cm}$ nos anos estudados, estão apresentadas na Tab. 1. A metodologia utilizada na análise de solo foi a descrita por Silva (1999).

As adubações de manutenção, em todos os anos de recuperação da pastagem, foram realizadas com base nos resultados das análises dos solos de cada ano. No primeiro ano (2003), foram aplicados $500 \mathrm{~kg} \mathrm{ha}^{-1}$ de calcário dolomítico com $85 \%$ de PRNT em cobertura 60 dias antes do período chuvoso. Em setembro, após as primeiras chuvas, foram aplicados $150 \mathrm{~kg} \mathrm{ha}^{-1} \mathrm{de}$ $\mathrm{P}_{2} \mathrm{O}_{5}, 80 \mathrm{~kg} \mathrm{ha}^{-1}$ de $\mathrm{K}_{2} \mathrm{O}$ e $30 \mathrm{~kg} \mathrm{ha}^{-1}$ de FTE BR12, utilizando como fontes: superfosfato simples, cloreto de potássio e fritas, respectivamente. 
Tabela 1. Resultados das determinações químicas do solo (análises realizadas antes da aplicação dos fertilizantes em cada ano)

\begin{tabular}{|c|c|c|c|}
\hline Característica do solo & 2003 & 2004 & 2005 \\
\hline pH (água) & 5,2 & 5,1 & 4,6 \\
\hline $\mathrm{Al}\left(\mathrm{cmol}_{\mathrm{c}} \mathrm{dm}^{-3}\right)$ & 0,0 & 0,1 & 0,2 \\
\hline $\mathrm{H}+\mathrm{Al}\left(\mathrm{cmol}_{\mathrm{c}} \mathrm{dm}^{-3}\right)$ & 3,9 & 4,5 & 5,3 \\
\hline $\mathrm{Ca}\left(\mathrm{cmol}_{\mathrm{c}} \mathrm{dm}^{-3}\right)$ & 2,70 & 2,79 & 2,20 \\
\hline $\operatorname{Mg}\left(\mathrm{cmol}_{\mathrm{c}} \mathrm{dm}^{-3}\right)$ & 1,00 & 0,91 & 0,23 \\
\hline $\mathrm{K}\left(\mathrm{cmol}_{\mathrm{c}} \mathrm{dm}^{-3}\right)$ & 0,42 & 0,23 & 0,11 \\
\hline P-Mehlich1 (mg dm$\left.{ }^{-3}\right)$ & 1,3 & 6,4 & 1,8 \\
\hline $\mathrm{SO}_{4}^{-2}\left(\mathrm{mg} \mathrm{dm}^{-3}\right)$ & 9,8 & 18,9 & 30,0 \\
\hline $\mathrm{Cu}\left(\mathrm{mg} \mathrm{dm}^{-3}\right)$ & 0,4 & 1,7 & 1,0 \\
\hline $\mathrm{Zn}\left(\mathrm{mg} \mathrm{dm}^{-3}\right)$ & 0,2 & 2,9 & 0,7 \\
\hline $\mathrm{Fe}\left(\mathrm{mg} \mathrm{dm}^{-3}\right)$ & 13,0 & 30,0 & 31,3 \\
\hline $\operatorname{Mn}\left(\mathrm{mg} \mathrm{dm}^{-3}\right)$ & 27,4 & 41,0 & 15,6 \\
\hline $\operatorname{MOS}\left(\mathrm{g} \mathrm{dm}^{-3}\right)$ & 11,0 & 18,0 & 20,0 \\
\hline CTC pH 7,0 $\left(\mathrm{cmol}_{\mathrm{c}} \mathrm{dm}^{-3}\right)$ & 8,0 & 8,4 & 7,8 \\
\hline $\mathrm{V}(\%)$ & 51,5 & 46,7 & 32,5 \\
\hline
\end{tabular}

MOS: matéria orgânica do solo; CTC: capacidade de troca cátion; V: saturação por bases.

A partir dos resultados da análise em amostra de solo do segundo ano (2004), foi realizada adubação de manutenção com $50 \mathrm{~kg} \mathrm{ha}^{-1}$ de $\mathrm{P}_{2} \mathrm{O}_{5}$ e $100 \mathrm{~kg} \mathrm{ha}^{-1}$ de $\mathrm{K}_{2} \mathrm{O}$, provenientes das fontes de superfosfato simples e cloreto de potássio, respectivamente. No terceiro ano de recuperação, 2005 , foram aplicados $150 \mathrm{~kg} \mathrm{ha}^{-1}$ de $\mathrm{P}_{2} \mathrm{O}_{5}, 120 \mathrm{~kg}$ $\mathrm{ha}^{-1}$ de $\mathrm{K}_{2} \mathrm{O}$ e $20 \mathrm{~kg} \mathrm{ha}^{-1}$ de FTE BR-12, na forma de super fosfato simples, cloreto de potássio e fritas, respectivamente. Toda a adubação de manutenção nos três anos foi realizada com uma única aplicação em cobertura, antes dos fertilizantes nitrogenados, no início do período chuvoso (setembro).

A adubação nitrogenada em cada ano foi aplicada em cobertura, parcelada em três épocas, após cada corte de avaliação da planta forrageira. A primeira aplicação foi realizada em dezembro, a segunda em janeiro e a terceira em fevereiro, com intervalo de trinta dias.

Foram realizados três cortes da planta forrageira por ano, no período das águas. O primeiro 30 dias após a aplicação dos fertilizantes nitrogenados (janeiro); o segundo 30 dias após o primeiro (fevereiro) e o terceiro 30 dias após o segundo (março).

A planta forrageira foi coletada com auxílio de um quadrado de ferro de $1 \mathrm{~m}$ x $1 \mathrm{~m}$ e cortada, com tesoura de aço, à altura de $20 \mathrm{~cm}$ da superfície do solo. Após cada corte de avaliação, foi realizado o corte de uniformização de toda a área experimental, na mesma altura de corte das plantas avaliadas, sendo retirado o resíduo resultante dessa uniformização.

O material coletado no campo foi acondicionado em saco plástico, identificado e enviado ao laboratório, onde foi pesado para determinação da massa verde coletada por parcela e, posteriormente, foi retirada uma amostra representativa da forragem de aproximadamente $500 \mathrm{~g}$. Em seguida, o material foi colocado em estufa de ventilação forçada de ar, com temperaturas entre $58^{\circ}$ e $65^{\circ} \mathrm{C}$, por 72 horas, para determinação da matéria seca parcial. Após a secagem, as amostras foram moídas em moinho do tipo Willey, com peneira de $1 \mathrm{~mm}$, armazenadas em sacos plásticos e identificadas.

A produção de massa seca por hectare foi determinada pela pesagem de todo o material da área útil da parcela e corrigida pelo teor de matéria seca obtido após o processamento das amostras.

Durante a condução do experimento, foram monitoradas diariamente as temperaturas médias e as precipitações pluviais, cujos resultados são mostrados na Fig. 1. 


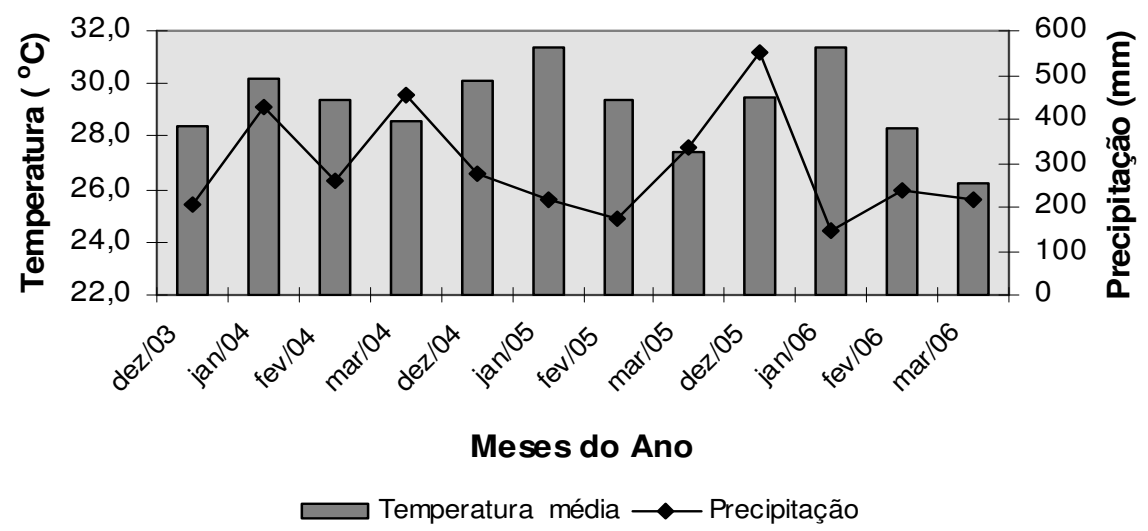

Figura 1. Temperaturas médias $\left({ }^{\circ} \mathrm{C}\right)$ e precipitações pluviais $(\mathrm{mm})$ observadas em São Luís de Montes Belos, GO.

A análise bromatológica foi realizada para determinação da proteína bruta (PB), da matéria seca (MS), da fibra em detergente neutro (FDN) e da fibra em detergente ácido (FDA), conforme metodologia de Silva e Queiroz (2002).

Os dados obtidos receberam tratamento estatístico pelo software Sisvar 4,6 (Ferreira, 1999). Inicialmente, foi realizada a análise de variância para as combinações das doses e fontes de nitrogênio, em que $o$ ano foi considerado como parcela subdividida no tempo. Em função da significância para essas variáveis, ajustaramse curvas de regressão. Utilizou-se o nível de significância de $5 \%$ em todos os testes estatísticos.

\section{RESULTADOS E DISCUSSÃO}

A produção de massa seca do capim-marandu foi influenciada pelas doses e fontes de nitrogênio e doses de nitrogênio e anos de recuperação. Quanto ao efeito de doses e fontes de nitrogênio, verificaram-se ajustes lineares da regressão para a produção de massa seca em função das doses de nitrogênio, para ambas as fontes (Fig. 2a). Na dose máxima de nitrogênio, a produção de massa seca na fonte de sulfato de amônio foi $18 \%$ mais elevada que na fonte de ureia. Isso pode ser explicado em função das transformações da ureia no solo, resultando em maiores perdas de nitrogênio por volatilização de amônia. Oliveira et al. (2007) relataram que as perdas por volatilização de amônia na ureia exigem atenção especial, principalmente quando aplicada a lanço em cobertura.
A magnitude do efeito das fontes de nitrogênio foi considerada pequena, devido à aplicação de enxofre em todas as parcelas, proveniente da adubação de manutenção dos três anos, com aplicação do superfosfato simples, pois houve enxofre suficiente para nivelar o efeito diferencial entre as fontes nitrogenadas utilizadas. É importante ressaltar que, em áreas que recebem grande quantidade de adubo nitrogenado, faz-se necessário o suprimento de enxofre para maximizar a resposta da forrageira, principalmente em áreas degradadas, com baixo teor de matéria orgânica, onde, normalmente, os teores de enxofre-sulfato encontram-se com baixa disponibilidade no solo (Bonfim-da-Silva e Monteiro, 2006). Mattos e Monteiro (2003) relataram que, em pastagem degradada de capimbraquiária, o enxofre contribui de forma efetiva na recuperação da planta forrageira, aumentando a produção e melhorando o seu valor nutritivo.

O aumento da produção de massa seca, obtida com a aplicação de $300 \mathrm{~kg}$ ha $^{-1}$ ano $^{-1}$ de nitrogênio, foi de $78 \%$ e $71 \%$ em relação à testemunha, para o sulfato de amônio e ureia, respectivamente. Estes resultados indicam a importância da adubação nitrogenada para a recuperação do capim-marandu, aspecto já mencionado por Bonfim-da-Silva e Monteiro (2006). Ydoyaga et al. (2006), ao trabalharem com métodos de recuperação de pastagens de Brachiaria decumbens, confirmaram essa importância, ao verificarem que a adubação nitrogenada proporcionou aumento de $34 \%$ na produção de massa seca na dose máxima estudada $\left(100 \mathrm{~kg} \mathrm{ha}^{-1}\right)$. 
(a)

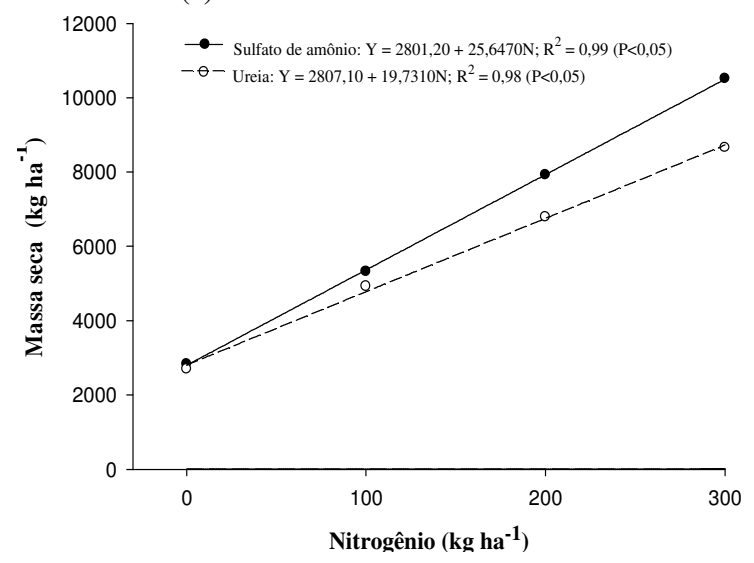

(b)

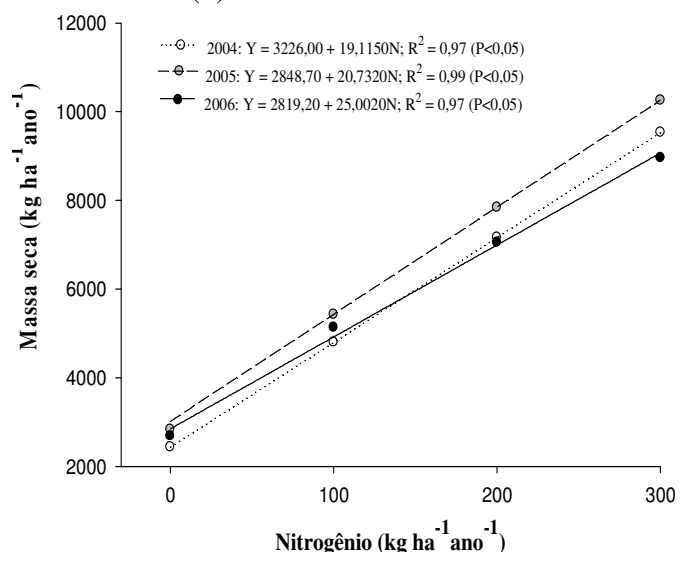

Figura 2. Produção de massa seca em função das doses e fontes de nitrogênio (a) e doses de nitrogênio e anos de recuperação (b) do capim-marandu (médias de três cortes por ano).

A produção de massa seca teve comportamento diferenciado na recuperação do capim-marandu, nos anos avaliados (Fig. 2b). Nos três anos, houve ajuste linear do efeito do nitrogênio na produção de massa seca. Nos anos de 2004 e 2005, em que as condições foram mais favoráveis ao crescimento da forrageira quanto à precipitação e à temperatura (Fig. 1), houve resposta acentuada ao nitrogênio na produção de massa seca, possibilitando discriminar diferenças significativas na produção em comparação com o ano de 2006.

A maior produção de forragem, em todas as doses de nitrogênio estudadas, foi observada no ano de 2005, quando ocorreu distribuição mais uniforme de chuvas, favorecendo a solubilização e o aproveitamento dos fertilizantes nitrogenados no solo. No ano de 2006, ocorreu queda de $11 \%$ em relação ao ano de 2004 na produção de forragem na dose máxima aplicada de nitrogênio, devido à ocorrência de um veranico no mês de janeiro, provocando deficit hídrico de 20 dias logo após a aplicação da adubação nitrogenada. Provavelmente, essa queda na produção de forragem foi ocasionada pela volatilização de nitrogênio, na fonte de ureia, logo após a aplicação, em função das altas temperaturas observadas e da falta de umidade do solo, limitando, com isso, as respostas ao nitrogênio e prejudicando a produção de massa seca. Sob condições de elevada temperatura, ausência de precipitação pluvial imediatamente após a adubação e altas taxas de evaporação de água do solo, as perdas por volatilização podem atingir até $80 \%$ do nitrogênio aplicado na forma de ureia, comprometendo a produtividade da planta forrageira.

A produção de massa seca obtida na dose máxima foi de $9.512 ; 10.075$ e $8.498 \mathrm{~kg} \mathrm{ha}^{-1}$, para os anos de 2004, 2005 e 2006, respectivamente. Primavesi et al. (2006), ao trabalharem com duas fontes (nitrato de amônio e ureia) e quatro doses de nitrogênio $\left(0,200,400\right.$ e $\left.800 \mathrm{~kg} \mathrm{ha}^{-1}\right)$ em Brachiaria brizantha $\mathrm{cv}$. Marandu, observaram que a produção da forragem na fonte de nitrato de amônio foi superior à da ureia, atingindo produções de 13.070 e $12.328 \mathrm{~kg} \mathrm{ha}^{-1}$ de massa seca, respectivamente, nas doses máximas.

As fontes de nitrogênio não influenciaram o teor de proteína bruta (PB) em todos os anos avaliados. Contudo, observou-se significância para as doses de nitrogênio e anos de recuperação da pastagem. Houve aumento linear no teor PB (Fig. 3) com acréscimo nas doses de nitrogênio, para todos os anos de avaliação, sendo os maiores teores observados na dose de $300 \mathrm{~kg} \mathrm{ha}{ }^{-1}$ de nitrogênio. Estes resultados indicam que o capim-marandu sob lotação intermitente com adubação nitrogenada proporcionou uma dieta com teores de PB que não limitariam a atividade microbiana no rúmen (Nutrient..., 2001). Em estudo de doses de nitrogênio e fósforo no capim-braquiária, Magalhães et al. (2007) verificaram que apenas o nitrogênio influenciou nos teores de PB, 
mostrando aumento de $22,5 \%$ na dose $100 \mathrm{~kg}$ de $\mathrm{ha}^{-1}$ de nitrogênio, quando comparada com a não aplicação de nitrogênio. A elevação dos teores de PB sob doses de nitrogênio também foi constatada por Lopes (2005), Mistura et al. (2007) e Benett et al. (2008).

Os maiores teores de PB nas doses máximas estudadas foram observados no ano de 2006, mostrando aumento de $47 \%$ e $32 \%$ em relação aos anos de 2004 e 2005, respectivamente. O maior teor obtido em 2006 pode ser atribuído em função da menor produção de massa seca na dose máxima aplicada de nitrogênio, ocasionado maior concentração de nitrogênio no tecido da planta (Costa et al., 2009) e influenciando no aumento do teor de PB.

Em estudo do efeito de fontes e doses de nitrogênio na produção e na qualidade da forragem de capim-coastcross (Cynodon dactylon), Corrêa et al. (2007) verificaram que o aumento das doses nas duas fontes de nitrogênio incrementou o teor de PB da forragem, variado de 14,7 a $15,3 \%$ para o nitrato de amônio e de 13,4 a $14,3 \%$ para a ureia.

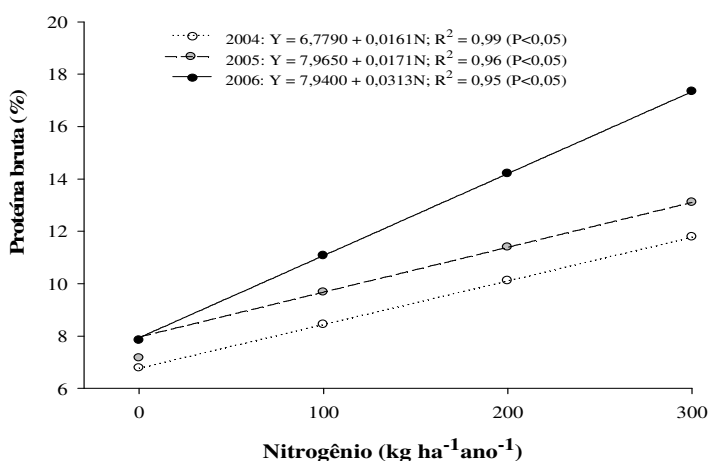

Figura 3. Teores de proteína bruta (PB) na matéria seca, em função das doses de nitrogênio e anos de recuperação do capim-marandu (médias de três cortes por ano).

Um aspecto importante a ser considerado no presente trabalho é a capacidade responsiva do capim-marandu à adubação nitrogenada, elevando o teor de PB para valores considerados adequados para o desenvolvimento da planta forrageira e contribuindo efetivamente para a recuperação da pastagem. Mesmo no tratamento sem adubação nitrogenada, o teor de PB ficou acima do nível crítico de 7\%, limitante do consumo pelos bovinos, em todos os anos de avaliação da pastagem. Esse fato é explicado pelo manejo de corte adotado, com períodos relativamente curtos de rebrota (30 dias), o que proporcionou forragem de melhor qualidade.

As fontes de nitrogênio e os anos de recuperação da forrageira não influenciaram nos teores de fibra em detergente neutro (FDN). Entretanto, houve influência das doses de nitrogênio, promovendo redução nos teores de FDN, com aumento da aplicação do nitrogênio (Fig. 4a). As médias ajustadas ficaram entre $70 \%$ a $64 \%$ para a testemunha e a dose máxima estudada, respectivamente, mostrando redução de $8,9 \%$ em relação à testemunha. Essa redução com o aumento das doses de nitrogênio é considerada relevante para a melhoria do valor nutritivo da forragem e para o aumento do consumo de massa seca pelos animais, pelo fato de o teor de FDN ser um importante parâmetro que define a qualidade da forragem, bem como limita a capacidade ingestiva por parte dos animais.

Em estudos de doses de nitrogênio (100, 200, $300,400 \mathrm{~kg} \mathrm{ha}^{-1} \mathrm{ano}^{-1}$ ) na composição bromatológica do capim-elefante, Mistura et al. (2007) verificaram que a adubação nitrogenada aumentou os teores de FDN. Outros autores, entretanto, não detectaram diferenças acentuadas nos teores de FDN em resposta à adubação nitrogenada (Costa et al., 2004).

A FDN representa a fração química da forrageira que se correlaciona mais estreitamente com o consumo voluntário dos animais, e valores acima de $55 \%$ a $60 \%$ correlacionam-se de maneira negativa (Van Soest, 1965). No presente trabalho, os valores de FDN encontrados estiveram sempre acima do valor crítico de $55 \%$ e, portanto, o consumo voluntário das forrageiras em pastejo poderia ser limitado no caso de uma pressão de pastejo alta, que reduziria a seletividade dos bovinos. Nussio et al. (2002) explicaram que forragens de alta digestibilidade de FDN proporcionam elevado potencial de consumo de massa seca e, consequentemente, maior produção de leite e de carne. Corrêa et al. (2007), ao estudarem o efeito de fontes e doses de nitrogênio na qualidade do capim-coastcross, verificaram maiores teores de FDN, em relação aos encontrados neste trabalho. As médias obtidas da adubação com ureia e com nitrato de amônio, independentemente das doses e dos 
cortes, foram de $81,8 \%$ e $81,1 \%$, respectivamente.

Apenas as doses de nitrogênio influenciaram nos teores de fibra em detergente ácido (FDA), mostrando decréscimo linear com o aumento das doses de nitrogênio (Fig. 4b). As médias ajustadas ficaram entre $41,14 \%$ a $30,33 \%$, com

(a)

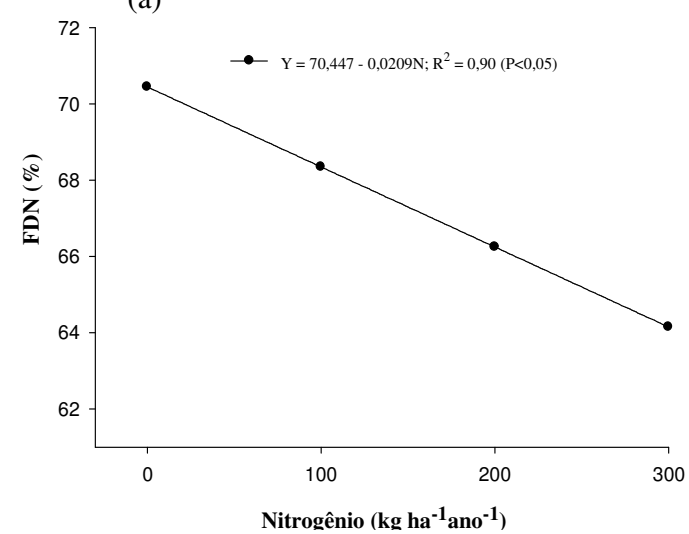

redução no teor de FDA na dose máxima de $26 \%$ em relação à não aplicação do nitrogênio. Esse decréscimo é considerado importante, pois o teor de FDA avalia a digestibilidade do alimento. Altos teores de FDA na planta forrageira diminuem a digestibilidade da massa seca, comprometendo o rendimento dos animais.

(b)

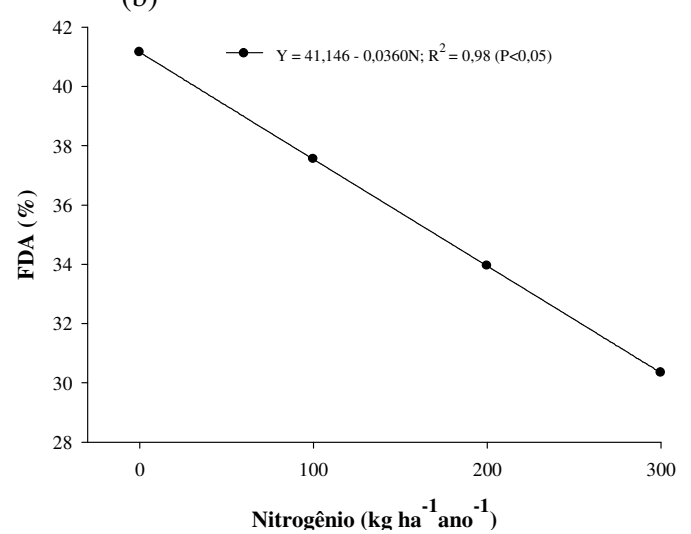

Figura 4. Teores de fibra em detergente neutro (FDN) (a) e fibra em detergente ácido (FDA) (b) na matéria seca, em função de doses de nitrogênio para o capim-marandu (média de três anos).

As adubações, principalmente a nitrogenada, além de aumentarem a produção de massa seca, aumentam o teor de PB da forragem e, em alguns casos, diminuem o teor de fibra, contribuindo, dessa forma, para a melhoria da sua qualidade (Burton, 1998). Costa et al. (2004), trabalhando com doses de nitrogênio, potássio e enxofre no capim-tanzânia, verificaram que a adubação reduziu o teor de FDA, ficando em torno de $36,2 \%$.

\section{CONCLUSÕES}

A aplicação de nitrogênio foi determinante para a recuperação do capim-marandu. A maior produção de massa seca foi observada no segundo ano e o maior teor de PB no terceiro ano de recuperação da pastagem. As maiores doses de nitrogênio promoveram acréscimos lineares na produção de massa seca e no teor de $\mathrm{PB}$ e redução nos teores de FDN e FDA. O sulfato de amônio resultou em maior produção de massa seca do que a ureia, em todas as doses e anos avaliados.

\section{REFERÊNCIAS BIBLIOGRÁFICAS}

ALEXANDRINO, E.; NASCIMENTO Jr., D.; REGAZZI, A.J. et al. Características morfogênicas e estruturais da Brachiaria brizantha cv. Marandu submetida a diferentes doses de nitrogênio e frequência de corte. Acta Sci., v.27, p.17-24, 2005.

BATISTA, K.; MONTEIRO, F.A. Respostas morfológicas e produtivas do capim-marandu adubado com doses combinadas de nitrogênio e enxofre. Rev. Bras. Zootec., v.35, p.1281-1288, 2006.

BENETT, C.G.S.; BUZETTI, S.; SILVA, K.S. et al. Produtividade e composição bromatológica do capim-marandu a fontes e doses de nitrogênio. Cienc. Agrotec., v.32, p.1629-1636, 2008

BONFIM-DA-SILVA, E.M.; MONTEIRO, F.A. Nitrogênio e enxofre em características produtivas do capim-braquiária proveniente de área de pastagem em degradação. Rev. Bras. Zootec., v.35, p.1289-1297, 2006. 
BURTON, G.W. Registration of Tifton 78 Bermuda grass. Crop Sci., v.28, p.187-188, 1998.

CORRÊA, L.A.; CANTARELLA, H.; PRIMAVESI, A.C. et al. Efeito de fontes e doses de nitrogênio na produção e qualidade da forragem de capim-coastcross. Rev. Bras. Zootec., v.36, p.763-772, 2007.

COSTA, K.A.P.; FRANÇA, A.F.S.; OLIVEIRA, I.P. et al. Composição química-bromatológica do capim-tanzânia em função de doses de nitrogênio, potássio e enxofre. Cienc. Anim. Bras., v.25, p.83-91, 2004.

COSTA, K.A.P.; FAQUIN, V.; OLIVEIRA, I.P. et al. Doses e fontes de nitrogênio na nutrição mineral do capim-marandu. Cienc. Animal Bras., v.10, p.115-123, 2009.

FAGUNDES, J.L.; FONSECA, D.M.; MORAIS, R.V. et al. Avaliação das características estruturais do capim-braquiária em pastagens adubadas com nitrogênio nas quatro estações do ano. Rev. Bras. Zootec., v.35, p.30-37, 2006.

FERREIRA, D.F. Sistema de análise de variância para dados balanceados - (software). Lavras: UFLA/DEX, 1999.

LOPES, R.S. Efeito da irrigação e adubação na disponibilidade e composição bromatológica da massa seca de lâminas foliares de capimelefante. Rev. Bras. Zootec., v.34, p.20-29, 2005.

MAGALHÃES, A.F.; PIRES, A.J.V.; CARVALHO, G.G.P. et al. Influência do nitrogênio e do fósforo na produção do capimbraquiária. Rev. Bras. Zootec., v.36, p.12401246, 2007.

MATTOS, W.T.; MONTEIRO, F.A. Produção e nutrição de capim-braquiária em função de doses de nitrogênio e enxofre. Bol. Ind. Anim., v.60, p.1-10, 2003.

MISTURA, C.; FONSECA, D.M.; MOREIRA, L.M. et al. Efeito da adubação nitrogenada e irrigação sobre a composição químicobromatológica das lâminas foliares e da planta inteira de capim-elefante sob pastejo. Rev. Bras. Zootec., v.36, p.1707-1714, 2007.

NUTRIENT requeriments of dairy cattle. 7.ed. Washington, DC: Academic, 2001. 381p.

NUSSIO, G.L.; CAMPOS, F.P.; PAZIANI, S.F. et al. Volumosos suplementares - estratégias de decisão e utilização. In: FORRAGICULTURA E
PASTAGENS: Temas em Evidência. 2002. Lavras. Anais... Lavras: UFLA, 2002. p.193-232.

OLIVEIRA, P.P.A.; TRIVELIN, P.C.O; OLIVEIRA, W.S. Balanço do nitrogênio $\left({ }^{15} \mathrm{~N}\right)$ da ureia nos componentes de uma pastagem de capim-marandu sob recuperação em diferentes épocas de calagem. Rev. Bras. Zootec., v.36, supl., p.1982-1989, 2007.

OLIVEIRA, P.P.A.; TRIVELIN, P.C.O; OLIVEIRA, W.S. et al. Fertilização com N e S na recuperação de pastagem de Brachiaria brizantha cv. Marandu em neossolo quartzarênico. Rev. Bras. Zootec., v.34, p.11211129, 2005.

PRIMAVESI, A.C.; PRIMAVESI, O.; CORRÊA, L.A. et al. Nutrientes na fitomassa de capim-marandu em função de fontes e doses de nitrogênio. Cienc. Agrotec., v.30, p.562-568, 2006.

SANTOS JÚNIOR, J.G.; MONTEIRO, F.A. Nutrição de capim-marandu submetido a doses de nitrogênio e idade de crescimento. Bol. Ind. Anim., v.60, p.139-146, 2003.

SILVA, F.C. Manual de análises químicas de solos, plantas e fertilizantes. Brasília: Embrapa Informação Tecnológica, 1999. 370p.

SILVA, D.J.; QUEIROZ, A.C. Análise de alimentos: métodos químicos e biológicos. 3.ed. Viçosa: UFV, 2002. 235p.

VAN SOEST, P.J. Symposium on factors influencing the voluntary intake of herbage by ruminants: voluntary intake relation to chemical composition and digestibility. J. Anim. Sci., v.24, p.834-44, 1965.

WERNER, J.C.; COLOZZA, M.T.; MONTEIRO, F.A. Adubação de pastagens. In: SIMPÓSIO SOBRE MANEJO DE PASTAGENS. 18., 2001, Piracicaba. Anais... Piracicaba: FEALQ, 2001. p.129-156.

YDOYAGA, D.F.; LIRA, M.A.; SANTOS, M.V.F. et al. Métodos de recuperação de pastagens de Brachiaria decumbens Stapf. no Agreste Pernambucano. Rev. Bras. Zootec., v.35, p.699-705, 2006. 
Arq. Bras. Med. Vet. Zootec., v.62, n.1, p.192-199, 2010 